\title{
Anny Teresy Tymienieckiej koncepcja dialogu interdyscyplinarnego
}

DOI: http://dx.doi.org/10.12775/RF.2014.016

Anna Teresa Tymieniecka (ur. 28.02.1923 - zm. 07.06.2014 roku) ${ }^{1}$, jak sama podkreślała, szła w swych rozważaniach drogą jaką filozofia podążała od samego początku, to znaczy od czasów starożytnych. Już w Pro$\log u$ do swej książki, zatytułowanej Życie w petni logos, autorka zdaje się przyznawać rację przekonaniu głoszonemu przez Sokratesa, a tak dobrze znanemu nie tylko filozofom: „im więcej wiem, tym wiem mniej”. Z punktu widzenia wiedzy, jaką posiada lub może posiadać człowiek współcześnie, owo Sokratejskie przekonanie ma dzisiaj jeszcze bardziej dobitną wymowę. Filozof zwraca uwagę, że wzrost wiedzy wcale nie oznacza wzrostu spokoju ducha ludzkiego, który zna i rozumie. Wręcz przeciwnie, oznacza raczej niepokój i wzmaga potrzebę zadawania ciągle nowych pytań 2 . Ale to jest właśnie to, czego człowiek potrzebuje najbardziej, by móc rozwijać się jako istota ludzka, jako osoba.

1 Anna Teresa Tymieniecka - współczesna polska filozofka, która od 1954 roku prowadziła akademicką działalność naukową w Stanach Zjednoczonych na Uniwersytecie Kalifornijskim w Berkeley (1954-1955), Yale University (1956-1958), St. Johns's University w Nowym Jorku (1970-1972). Znana jest między innymi jako redaktor naczelna założonej przez siebie w 1968 roku serii wydawniczej Analecta Husserliana. The Yearbook of Phenomenological Research, a także czasopisma „Phenomenology Information Bulletin”, od 1985 roku wydawanego pod tytułem: „Phenomenological Inquiry. A Review of Philosophical Ideas and Trends”. Zob. A. Szymaniak, Anna Teresa Tymieniecka, hasło w: Encyklopedia filozofii polskiej, red. A. Maryniarczyk, t. 2, Polskie Towarzystwo Tomasza z Akwinu, Lublin 2011, s. 759-762.

2 Por. A.T. Tymieniecka, Życie w petni logos, ks. 1: Metafizyka Nowego Oświecenia, przeł. M. Wiertlewska, Wydawnictwo Poznańskie, Poznań 2011, s. 11-12. 
Obrany przez Tymieniecką kierunek rozważań filozoficznych jest próbą odnalezienia właściwej drogi poznania sensu Wszystkiego (będąc wiernym gramatyce jej języka). Jednocześnie stoi ona na stanowisku, w ramach którego stara się pokazać, że zarówno narzędzia, jak i metoda takiego poznania zostały już przez dotychczasową filozofię wyłuszczone, chociaż z perspektywy rozwijającej się wiedzy, w czym pokaźny udział ma nauka (science), ale również działalność artystyczna i oczywiście filozoficzna, wręcz wymagane jest, by na tę kwestię spojrzeć od nowa.

Z jednej strony współcześnie możemy ze znacznie szerszej niż dotychczas perspektywy przyglądać się światu i badać nasze w nim miejsce, a $\mathrm{z}$ drugiej poszerzające się horyzonty uruchomiły swego rodzaju "atmosferę podejrzeń", w związku z jednoczesnym wzrastaniem w nas świadomości naszej niewiedzy, a w perspektywie wiedzy przez nas posiadanej. Doprowadza ona dzisiaj ludzkość do tych samych pytań, jakie już wieki temu zadawał człowiek, a na jakie wówczas, idąc tropem myśli autorki Życia w petni logos, nie mógł udzielić tak głębokiej i wyczerpującej odpowiedzi, jak obecnie.

A jednak dziś, tak jak i dawniej - pisze Tymieniecka - tajemne zagadki rzeczywistości i ludzkiego poznania nadal są rozjaśniane, a "pierwsze” zasady nie zniknęły zupełnie z pola widzenia. [...] chociaż nasze widzenie rzeczywistości i ludzkiego $\mathrm{w}$ nią zaangażowania diametralnie przesunęło się z wyżyn spekulatywnego rozumu ku pierwotnej konkretności i jej źródłom, drogi prowadzące do tych źródeł kierują nasze poszukiwania ku ostatecznym, tak ostentacyjnie porzuconym pytaniom ${ }^{3}$.

Dzisiaj stajemy przed możliwością nową na tyle, by mówić o „nowym oświeceniu"4, wskazującym potrzebę przeprowadzenia nowej krytyki rozumu. Wciąż chodzi o wiedzę pewna, niebudzącą wątpliwości, a przede wszystkim - naukową. Jest to wyzwanie kulturowe. Jego podejmowanie cechuje ludzkie współczesne myślenie, kształtowane przez naukę, filozofię i sztukę. Te trzy dziedziny są tymi, którymi „posługuje się" człowiek, wyrażając swe poznanie rzeczywistości. Przy czym nie należy sądzić, jakoby każda z nich: nauka, filozofia i sztuka - każda z osobna - ujmowały określoną część rzeczywistości. Struktura rzeczywistości, jaką autorka kreśliła przez ponad 40 lat swej pracy badawczej, stanowi fundament budowanej przez nią koncepcji naukowego dialogu interdyscyplinarnego. Na marginesie należy podkreślić, że tematyka ta nie stanowi nici przewodniej badań autorki, ale jest $\mathrm{w}$ nich mocno obecna i widoczna w samym sposobie rozumienia rzeczywistości. Wy-

3 Ibidem, s. 13-16.

4 Zob. ibidem, s. 19. 
daje się zatem, że podejście Tymienieckiej do rozumienia rzeczywistości stanowi próbę pokazania, iż rzeczywistość jest w gruncie rzeczy jednością a jako wielość uzasadniająca wielorakie do niej podejście badawcze, jest wielością w jedności. Dlatego nauka, filozofia oraz działalność artystyczna są próbą ujęcia rzeczywistości w jej całokształcie, chociaż tylko z pozycji określonej racjonalności. To, czego dziś potrzebuje człowiek, to „wspólny mianownik” dla wszystkich racjonalności - racjonalnych uzasadnień rzeczywistości, którymi człowiek włada, i które niezmiernie poszerzają jego horyzonty 5 .

Ów wspólny mianownik pozwoliłby, zdaniem Tymienieckiej, na badanie najgłębszych obszarów rzeczywistości. W tym kontekście filozof pisze: „Stan naszej kultury przynagla nas do poszukiwania rozumu. Obecny stan rzeczy woła o ratunek pochodzący od samego rozumu; woła o filozofię, która uwolniłaby nas z impasu, w jakim tkwimy, i poprowadziłaby dalej"6. Natomiast gdzie indziej autorka podkreśla:

W filozofii należy więc uwzględnić nie tylko nasze bardziej fundamentalne rozumienie struktury człowieka i ludzkiego umysłu w jego ewolucyjnym rozwoju, lecz również współczesne wyjaśnienia dotyczące natury języka $\mathrm{w}$ budowaniu rozumienia rzeczywistości. $\mathrm{W}$ tym celu wypracowane są ściślejsze postulaty wnioskowania i kryteria pewności, które domagają się krytycznej oceny koncepcji dotychczas uznawanych $\mathrm{w}$ badaniach filozoficznych, np. podmiot i przedmiot, indywiduum i społeczność, istota i istnienie, substancja i przypadłość. Ponadto należy docenić znaczenie nowych wglądów w problematykę ogniw łączących, nici komunikacyjnych itp., które prowadzą nas do bardziej adekwatnego obrazu rzeczywistości ${ }^{7}$.

Tym wspólnym podłożem współpracy różnych dyscyplin ludzkiej działalności intelektualnej jest filozofia: filozofia podmiotu, filozofia życia - fenomenologia życia.

Jedynie nowe ramy odniesienia mogą uwzględnić nową modalność wszystkich zróżnicowań, jedynie autentyczna mathesis universalis dysponuje alfabetem mającym wielostronnie przekazać pełny sens tworzenia: konstruktywizm, energię, metamorficzną różnorodność, siłę pobudzającą wzrost i rozkład w odradzających źródłach Nieuwarunkowanego ${ }^{8}$.

To filozofia dająca możliwość zbudowania jednego, najbardziej adekwatnego obrazu rzeczywistości, tak jak jedna i spójna jest w gruncie rzeczy sama rzeczywistość.

5 Zob. ibidem, s. 18-19.

6 Ibidem, s. 17.

7 Ibidem, s. 13.

8 Ibidem, s. 19. 
Przedmiotem bezpośredniej refleksji filozofii życia nie staje się tutaj starożytna zasada wszelkich zasad, jakkolwiek mathesis uniwersalis do jej poznania dąży i takie poznanie zakłada. Tymieniecka nie czyni nim również absolutnych, uniwersalnych struktur ludzkiego umysłu, jak czyniła to filozofia nowożytna, chociaż struktury te mogą się poznawczo odsłonić wraz $\mathrm{z}$ wchodzeniem $\mathrm{w}$ coraz głębsze poziomy racjonalności rzeczywistości. „Mamy tu więc do czynienia z filozofią - proto-fenomenologią - jestestwa życia. Stajemy tu bowiem wobec ontopojetycznego ${ }^{9}$ wglądu w kuźnię, w której wykuwa się racjonalności"10.

Tymieniecka poddaje oglądowi rzeczywistość, stawiając przed oczyma badacza świat życia, świat istot żywych (living agents) żyjących $\mathrm{w}$,"jedności-ze-wszystkim-co-żyje" (the-unity-of-everything-there-is-alive). Tak rozumianą rzeczywistość można poznać tylko przez pojęcie tego, czym jest rodzenie się i na czym polega rozwój żywego jestestwa ${ }^{11}$. Autorka sama wskazuje, że jej podejście do kwestii zrozumienia rzeczywistości przez wskazanie jej pochodzenia, lub chociażby prawdopodobnego sposobu jej powstania, zgadza się z postulatem Gottfrieda W. Leibniza ${ }^{12}$. W prezentowanej tu koncepcji filozofii życia, genezą życia jest logos życia. „Ten sam” starożytny logos, ale odkrywany na nowo „w labiryncie nowych danych odsłaniających rzeczywistość [...]. Logos, sens sensu, przenika Wszystko; obejmuje ludzką rzeczywistość, całokształt rozbłyskujących fal, nasze nowe kulturowe oświecenie, jak też i wszystko, co dopiero ma nadejść. IN LOGOS OMNIA!"13

Ontopojeza życia daje nowy dostęp do logos. Duch naszych czasów, jak twierdzi autorka, wymaga od nas tego, by na świat i życie spojrzeć z perspektywy przyrody, a nawet z perspektywy geokosmicznej. Posługując się terminologią samej autorki, zyskamy tym sposobem dostęp do wiedzy o „pozycjonowaniu się" ludzkiej kondycji wewnątrz jedności-ze-wszystkim-co-żyje:

Twierdzę, iż żywe jestestwo rozpoznaje siebie jako „siebie” nie przez akt poznawczy, lecz przez bycie „żywym”, doświadczając siebie wewnątrz otoczenia swego jestestwa, kierując swymi instynktami i pragnieniami,

9 Tymieniecka podkreśla, że tym, co radykalnie odróżnia żywy byt od innych rodzajów bytu, jest zdolność do właściwego sobie powielania się, czyli dokonywania replikacji. Proces ten „wybucha” $\mathrm{z}$ wewnątrz samego indywiduum. W procesie tym indywiduum replikuje cechy charakterystyczne dla całego typu, do jakiego należy, nie tracąc przy tym swej indywidualności, a jednocześnie rozwija cechy, którymi już na zawsze wzbogaca cały swój typ. Te tendencje podtrzymują się wzajemnie i wzbogacają. Zob. M. Wiertlewska, Objaśnienia ważniejszych pojęć, w: A.T. Tymieniecka: Życie w petni logos, s. 389-390.

10 Ibidem, s. 20.

11 Por. ibidem, s. 19.

12 Zob. ibidem, s. 105.

13 Ibidem, s. 19. 
rozpoznając elementy otaczającego świata w ich witalnym związku z[e] sobą i wreszcie, co najważniejsze, rozpoznając siebie jako działające centrum uniwersum egzystencji, jako samodzielny podmiot sprawczy, który kieruje tym uniwersum od wewnątrz, przez doświadczanie, obserwację, refleksję i namysł nad kursem, jakim podąża, i kto ostatecznie obdarza ten kurs moralnymi i estetycznymi wartościami, a na skrzydłach ducha dąży do zrozumienia powodów tego wszystkiego i wzbija się wysoko w dziedzinę metafizyczną i duchową, niosąc w sobie dogłębne odczuwane przeświadczenie, że być to być żyjącym ${ }^{14}$.

To ogromnie wiele mówiący na temat koncepcji fenomenologii życia cytat. Istota ludzka, przeżywając swoje bycie w świecie, swoje w nim istnienie, przede wszystkim przeżywa siebie jako żyjąca, a następnie jako żyjącą w jedności-ze-wszystkim-co-żyje. Fenomenologia życia musi uwzględniać pierwszoplanowo treść tych ludzkich przeżyć, jeśli podejmuje w swych badaniach zagadnienie sensu życia ${ }^{15}$. Samo pytanie o sens życia, zdaniem filozofki, jest takim, które niezależnie od czasu, w jakim rozwija się filozofia, jak również nauka i szeroko rozumiana działalność artystyczna, wciąż powraca na nowo. Od odpowiedzi na to pytanie zdaje się zależeć przyszłość ludzkiej wiedzy, a wraz z nią ludzkiego sposobu rozumienia własnej przyszłości oraz swoistego przeznaczenia ludzkości. „Na początek wystarczy odnotować potrzebę ustanowienia sieci współdziałania między różnymi płaszczyznami rzeczywistości, które mnożą się wraz z podejmowaniem przez nas prac interdyscyplinarnych we wszystkich obszarach badań i działań praktycznych"16.

Egzystencjalne korzenie człowieka tkwią w tzw. pierworodnej matrycy przyrody, lub inaczej - w „łonie życia”, w którym zawarte są wszystkie prawa rządzące ewolucją. Tymieniecka nazywa je „prawami konstruktywnymi". Ustanowione przez logos życia prawa określają warunki przebiegu procesu ewolucji, zwanego procesem indywidualizacji. W rzeczonej matrycy, której charakter przyrodniczy nie podlega tutaj dyskusji, zakotwiczone są również energie, siły i dynamizmy, ja-

14 Ibidem, s. 26.

15 „Życie jest dynamicznym strumieniem przemian, lecz niewiele ma wspólnego z nieokiełznanym strumieniem heraklitejskim, gdyż w odróżnieniu od niego uspójnia się. Przede wszystkim »czasowi się« przez wszystkie kolejno po sobie następujące interrogatywne kroki konstruktywnego/destruktywnego stawania się. Jego wielokierunkowa siła napędowa tkwi faktycznie w konstruktywnym élan, które jako élan formułuje pytania adresowane do swoich możliwości. Każdy dokonany krok rodzi "pytanie " odnośnie do następnego, to znaczy - ustanawia porządek dynamiki. Za pomocą tej sztafety pytań logos życia, działający w obrębie przenoszonej przez siebie sieci ontopojetycznych wzorów konstrukcyjnych, przekształca strumień swoich sił z chaosu w zorganizowane stawanie się - stawanie się życia i elementów z nim uzgadnianych". M. Wiertlewska, Objaśnienia ważniejszych pojęć, s. 393.

16 A.T. Tymieniecka, Życie w petni logos, s. 17. 
kie uczestniczą $\mathrm{w}$ dalszym rozwoju życia i wyłaniania się w jego toku poszczególnych indywiduów - żywych jestestw. Tu również działa logos, który inicjuje ten konstruktywny proces. Wraz z siłami i energiami, pierwotnie zawartymi $\mathrm{w}$ łonie życia, tkwią $\mathrm{w}$ nim również wirtualności - mówiąc w skrócie: możliwe postaci rzeczywistości. Ich urealnianie się, aktualizowanie podporządkowuje się warunkom, w jakie w danym momencie wchodzi strumień życia. Inaczej mówiąc, taka, a nie inna indywidualna postać życia wyłoni się ze strumienia życia i takie, a nie inne cechy (modalności) będzie ona posiadała, jeżeli pozwolą na to określone warunki otoczenia, z którymi konfrontują się zasady i prawa $\log$ os życia ${ }^{17}$.

Nie wchodząc w szczegóły całego procesu indywidualizacji, szczegóły, których nie brak w opisach autorki, dla dobra omawianej tu sprawy należy przenieść się na koniec całego procesu indywidualizacji. Wyłaniające się $\mathrm{w}$ strumieniu życia jestestwo stanowi postać urealnionych wirtualności, które zostały zaktualizowane przy wykorzystaniu pierworodnych sił i energii obecnych $\mathrm{w}$ łonie życia. Lecz energii tych nie ubywa. Wręcz przeciwnie. Każda nowa postać życia i każdy nowy element życia wnosi ze sobą do strumienia życia nowe dynamizmy o potencjale, którego wcześniej nie było, a które dalej pracują na rzecz rozrastania się całej sieci życia. Tak się dzieje od początku: od pierwszej żywej komórki, przez rośliny, zwierzęta (o coraz wyższym stopniu świadomości), aż po istotę ludzką ${ }^{18}$. Co to oznacza dla człowieka? Ludzka kondycja wyłania się w strumieniu życia w jedności-ze-wszystkim-co-żyje jako określony, ostatni etap procesu indywidualizacji (ontopojezy życia). W spotęgowaniu ludzkich sił w sieci życia biorą udział wszystkie tzw. funkcjonalne układy ludzkiego ciała (układ krwionośny, pokarmowy, oddechowy i inne), lecz szczególna zasługa leży po stronie układu nerwowego i tego organu, jakim jest ludzki mózg. To jemu de facto człowiek zawdzięcza swą wysoką i niepowtarzalną pozycję w sieci życia, a jego kondycja jest kondycją twórczą. Wraz z rozwojem mózgu świadomość zmysłowa (sensoryczna) ewoluuje w świadomość prezentacyjną i konstytutywną jak rzecz określa autorka ${ }^{19}$. A zatem świadomość ludzka, jej intencjonalność oraz twórczość, tak często zdająca się walczyć z surowością natury, odsyłając nas do swej genezy, wskazuje na tę samą matrycę życia, która odpowiada za reprodukcję jestestw żywych ${ }^{20}$.

17 Por. eadem, The Human Condition in-the-Unity-of-Everything-there-is-alive. Individuation, Self, Person, Self-determination, Freedom, Necessity, "Analecta Husserliana. The Yearbook of Phenomenological Research" 2006, vol. 89, book 2, s. XV-XVI.

18 Zob. eadem, Życie w petni logos, s. 117.

19 Zob. eadem, The Human Condition in-the-Unity-of-Everything-there-is-alive. Individuation, Self, Person, Self-determination, Freedom, Necessity, s. XX-XXII.

20 Zob. eadem, Poetics as the two faced mirror of the human being In phenomenology and literature, "Analecta Husserliana. The Yearbook of Phenomenological Research" 
Tymieniecka mówi o "pozycjonowaniu się": "przestrzenieniu” i „,czasowieniu” się ludzkiej kondycji w jedności-ze-wszystkim-co-żyje. Ewolucyjny proces, który tutaj przybiera postać indywidualizowania się jestestw żywych, ich pozycjonowania w sieci życia (net of life), nie dokonuje się w sposób przypadkowy, „ślepy”. Każde jestestwo łączy się z innymi jestestwami za sprawą różnorakich powiązań i zależności, jak gdyby „przemyślanymi”. „Przemyślana” jest również ludzka kondycja twórcza, za sprawą której, w sposób spotęgowany potencjałem ludzkiego mózgu, ,życie przędzie swój sens jak pająk nić" ${ }^{\prime 21}$.

Całokształt procesu indywidualizacji Tymieniecka opisuje z dużo większą dokładnością, niż to zostało przedstawione. Dzięki temu można dostrzec, że rysuje ona ewolucjonistyczny, a zarazem metafizyczny obraz świata i człowieka. Ewolucjonizm nie ma tutaj tylko znaczenia biologicznego. Dlatego również problematyka sensu życia, racjonalności życia, nie sprowadza się wyłącznie do rozważań czysto przyrodniczych, wobec których filozofia miałaby tylko przyjąć jakieś stanowisko. Ta problematyka ma w gruncie rzeczy znaczenie metafizyczne i o taki, głęboki sens należy się starać, doprowadzając do interdyscyplinarnego dialogu naukowego. Autorka pisze: „Paradoksalnie istota ludzka zdaje się integralną częścią przyrody, a jednak sięga poziomów "poza przyrodą", poziomów życia obdarzających istotę ludzką specjalnym, niepowtarzalnym znaczeniem, które nie jest już po prostu witalne, lecz także duchowe" 22 . W związku z tym wyłania się nie tylko potrzeba komunikowania się poszczególnych dyscyplin nauk przyrodniczych (biologii, chemii, fizyki), które zajmują się fenomenem życia w kategoriach przetrwania (survival), lecz równie ważne znaczenie w badaniach nad życiem jako takim i życiem ludzkim mają nauki społeczne, humanistyczne, które - najkrócej rzecz ujmując- interesują się człowiekiem jako istotą społeczną i jego twórczością. Nauki szczegółowe odsłaniają powiązania i zależności zachodzące pomiędzy witalnymi siłami i procesami, których podmiotem i przedmiotem jawi się również człowiek - istota ludzka (human being) ${ }^{23}$. Nauki społeczne poddają oglądowi siły i procesy społeczne, ale ich podmiotem jest jedynie człowiek, przedmiotem zaś zdaniem Tymienieckiej - cały świat życia, z którym istota ludzka wchodzi w interakcje o charakterze przyrodniczym. Wszystkie te elementy muszą zostać wzięte pod uwagę, gdy celem wiedzy staje się wyrażenie kondycji ludzkiej. One tę kondycję wyrażają a jednocześnie ją kształtują co oznacza tutaj, że kondycja ludzka staje się źródłem wiedzy na temat kształtujących ją czynników: witalnych i społecznych, kierunku ich

1982, vol. 12, s. IX, s. 10-18.

21 Zob. eadem, Życie w petni logos, s. 21.

22 Ibidem, s. 294.

${ }^{23}$ Zob. ibidem, s. 17. 
rozwoju, zmian, jakim podlegaja, a przede wszystkim swoistej zasady, na której opierają swoje siły i swój dynamizm.

Jedność rzeczywistości zostaje zobrazowana przez autorkę w postaci ogromnej sieci wzajemnych powiązań, której poszczególne elementy istoty żywe - wypuszczają przed siebie "czułki", sięgając coraz dalej, łącząc się nie tylko z tym, co już żyje, co istnieje, ale także wyznaczając nowy, dalszy kierunek własnego i ogólnie życiowego rozwoju. Ludzką kondycję należy pojmować jako ukształtowaną wieloczynnikowo (mówiąc w skrócie). W grę wchodzą bowiem czynniki biologiczne (geokosmiczne), ale także społeczne i kulturowe, a człowiek ujmowany jest poznawczo całościowo, jako żywa tkanka-ciało-psychika-dusza. Żadnemu z tych elementów nie sposób przypisać roli faworyta, żadnego nie można nie docenić. Na marginesie warto nadmienić, że nieadekwatne wydaje się zresztą określenie „element”, gdyż niesłusznie może wskazywać na możliwość oderwania, odseparowania któregokolwiek z nich w celu poddania go analizom, pozwalającym poznać ludzką istotę $\mathrm{w}$ całości. Dlatego używa się go w niniejszej wypowiedzi jedynie pomocniczo i na poziomie lingwistycznym.

To ogromnie pojemne zadanie, jakie stawia sobie fenomenologia życia, a którym jest poznanie i zrozumienie sensu życia, wymaga znalezienia wspólnego frontu dla działań wszystkich dyscyplin intelektualnych i duchowych. Każda z nich, z własnego punktu widzenia i posługując się własną metodą (a nawet metodami) oraz własnym językiem (a nawet językami), stara się ów sens ująć. Dlatego kwestia języka używanego przez autorkę także ma swój udział w budowaniu interdyscyplinarnego dialogu. To język łączący terminologię różnych dziedzin: dyscyplin naukowych opisujących witalny świat, systemów filozoficznych, tworzonych przez wieki w różnych miejscach świata i różnych okresach, nauk społecznych analizujących międzyludzkie więzi społeczne, język z dziedziny estetyki, a nawet literatury. Niemało w nim metafor, gdyż język poezji wydaje się Tymienieckiej najbardziej precyzyjnym typem wymowy treści ludzkiego wnętrza, ludzkiego umysłu i ludzkiej duszy. To stamtąd fenomenologia czerpie treści poznawcze, tworzące najbardziej adekwatny obraz rzeczywistości, posługując się bezpośrednim, intuicyjnym wglądem.

Taki właśnie - metaforyczny, syntetyzujący, a dzięki temu bardzo wiele mówiący - jest język autorki Życia w pełni logos i zarazem język fenomenologii życia. To język, który daje porozumienie filozofii, nauce i działalności artystycznej. Dlatego Tymieniecka bada i naukę, i sztukę pod kątem ich „filozoficzności”, co tutaj oznacza próbę pokazania, że każda z nich - sztuka, literatura, poezja, ale także nauka, zwłaszcza 
nauka współczesna - zawiera sporą dozę filozoficznej refleksji ${ }^{24}$. Nowa filozofia jest w mocy stworzyć wspólną dla nich i dla ludzkiego umysłu płaszczyznę działań poznawczych (badań naukowych, wiedzotwórczych).

Należy podkreślić, że współpraca ta nie ma na celu sprowadzenia działalności artystycznej i literackiej oraz naukowej do tworzenia filozofii. Każda z nich działa we własnym zakresie. I tak ma być. Nie zmienia to jednak faktu, że filozofia tworzy się niejako sama, wraz z rozwojem działalności wiedzotwórczej człowieka. Trzeba ją zatem wydobyć, wyłonić, a nawet uświadomić sobie jej obecność w ludzkim życiu na co dzień. Taka, jak się wydaje, jest fenomenologia życia - filozofia, która wyrasta z życia i do życia się odnosi. Jej język to język służący opisowi tego, co bezpośrednio, intuicyjnie poznane, gdyż tylko wyrażone, treści te mogą mieć charakter naukowy, komunikowalny i interdyscyplinarny.

Tymieniecka za niezmiernie ważny krok w rozwoju filozofii, zmierzającej do ujęcia sensu życia, uznaje ukształtowanie się stanowiska Kartezjusza. Myśliciel ten dostrzegł siłę oddziaływania log os in te r rog a cji, charakterystycznego dla ludzkiej kondycji twórczej. Wątpienie, podobnie jak zdziwienie, kieruje człowiekiem od początku jego życia, aż po sam koniec. Potwierdzenie tego odnajdujemy w życiu indywidualnym każdego człowieka, jak również w życiu ludzkości jako pewnej historycznej całości, rozumianej w kategoriach przyrodniczych i społecznych. Wątpienie zatem jako forma zadawania pytań, które napędzają rozwój ludzkiej wiedzy, jest czymś oczywistym i w oczywisty sposób charakteryzującym ludzki sposób postrzegania siebie we wszechświecie. Jednak obrany przez Kartezjusza punkt wyjścia wiedzy pewnej i oczywistej, a przez to naukowej, przyjęcie za ten punkt rzeczy myślącej, odseparowanej od wszelkiej rozciągłości (przestrzenności i czasowości), doprowadziło jedynie do oddzielenia dwóch obrazów ludzkiego funkcjonowania. Tymieniecka podkreśla, że również Edmundowi Husserlowi, chcącemu przezwyciężyć ów dualizm, nie powiodło się wypracowanie właściwego poznawczego punktu wyjścia ${ }^{25}$. Wspólnie dziedziny ludzkiej racjonalności: artystyczna, naukowa i filozoficzna, w ich ogromnym postępie, pokazują dzisiaj, że rzeczywistość jest spójna i taką winna ją przedstawiać adekwatna wiedza. Tym samym upada Kartezjański dualizm duszy i ciała, negujący udział tego drugiego elementu zarów-

24 "Both the poet and philosopher, whether in the poetic or a scholarly way, attempt to penetrate to the hidden springs of experience - what the phenomenologist calls »pre-given «, "pre-objective«, or "pre-predicative«; to designate it, poets use an infinite variety of expressions [...]. They both share a similar metaphysical inquisitiveness". A.T. Tymieniecka, Poetics as the two faced mirror of the human being. In phenomenology and literature, s. 5.

${ }_{25}$ Zob. eadem, Życie w petni logos, s. 335. 
no w procesie budowania wiedzy, jak i konstytuowania ludzkiej osoby. W ewolucyjnej koncepcji fenomenologii życia myśl nierozerwalnie łączy się z ciałem człowieka za sprawą mózgu. Za jego pośrednictwem łączy się ona też z całym światem żywych jestestw w sieci wzajemnych powiązań. I nie chodzi tu tylko o relacje społeczne, międzyludzkie, ale także o powiązania o charakterze ekologicznym ${ }^{26}$.

Tym właściwym punktem wyjścia poznawczych zmagań człowieka, które ujawniają spójność rzeczywistości i to, że jest ona jedna, jest ludzkie doświadczenie twórcze ${ }^{27}$. Jego źródło tkwi we wzajemnych powiązaniach wszystkich poziomów racjonalności, na których działa i przejawia się logos życia. Tymieniecka pisze:

Po wnikliwym i żmudnym odkrywaniu kolejnych poziomów racjonalnych podstaw życia w ich wzajemnych powiązaniach u źródeł ludzkiego doświadczenia twórczego, jestem przekonana, że dotarłam do drzwi prowadzących do sekretu życia: do log os ży cia w jego czystej modalności, na jego ontopojetycznym, konstruktywnym kursie, inicjującym pierwsze poruszenia genezy jestestwa oraz źródłowe wkroczenie jestestwa w realność i rozwój je.

Logos życia to Rozum obecny w ludzkiej działalności i myśleniu filozoficznym, artystycznym i naukowym (science). To Rozum, który kieruje tymi doświadczeniami i konstytuowaniem ich treści. Życie drzewa jest dowodem jego działania i wyrazem przejawiania się, podobnie jak fakt uprawiania przez człowieka refleksji filozoficznej, estetycznej i moralnej. To logos życia powoduje, że człowiek może kochać i rozprawiać o tym, że kocha właśnie w określony sposób. Czyni to również z danej perspektywy. Owe sposoby i perspektywy wyrażają modus ludzkiego życia, rozpatrywanego z punktu widzenia życia konkretnego człowieka i dlatego wydaje się, że może ich być nieskończenie wiele. Czy tak jest w rzeczywistości, trudno rozsądzić, gdyż człowiek nawet nie zbliżył się do końca rozwoju swej twórczej kondycji. Ona wciąż dąży do Transcendencji.

Twórczość zatem to właściwość logos życia ujawniana za sprawą kondycji jestestw żywych. Wraz z kondycją ludzką uobecnia się w świecie niepowtarzalny element twórczy, jakim jest imaginatio creatrix. Udział tego czynnika w kształtowaniu ludzkich aktów twórczych powoduje, że stają się one najznakomitszą drogą ku najgłębszym i zarazem naj-

26 Problematyką ekologii w ramach teorii zrównoważonego rozwoju w oparciu o koncepcję fenomenologii życia Tymienieckiej analizuje Ignacy S. Fiut. Zob. I.S. Fiut, Zrównoważony rozwój: aspekt filozoficzny i medialny, „Problemy Ekorozwoju” 2006, t. 1, nr 2, s. 25-32.

27 Zob. A.T. Tymieniecka, Życie w petni logos, s. 19-20.

28 Ibidem, s. 19. 
wyższym pokładom rzeczywistości - ku samemu czystemu logos życia. Jednocześnie wzajemne powiązania w obrębie różnych poziomów ludzkiego życia stają się jeszcze bardziej oczywiste. Dzięki imaginatio creatrix, twierdzi Tymieniecka, do ludzkiego życia zostaje wprowadzony sens intelektywny, estetyczny i moralny. Ten pierwszy ustanawia porządek świata, drugi wychodzi poza pragmatyczne pojmowanie tego, co witalne, trzeci zaś wyznacza moment przejścia między sferą witalną a swoistością ludzkiej kondycjii ${ }^{29}$.

Istota ludzka jest więc podmiotem najwyższej postaci poznania. Niepodważalny udział w nim ma świadomość ludzka, ale świadomość zakotwiczona w całości cielesno-duchowej, zapodmiotowana w ludzkim ciele, w mózgu człowieka. Jest ona samo-świadomością ale nie jakimś samo-bytem, podmiotem samym w sobie, co zostało już zasygnalizowane. Świadomość ludzka działa i poznaje w strumieniu życia, z którego "wydobywa" ją logos życia, ale sama takim strumieniem nie jest. W myśli Edmunda Husserla to świadomość przeniknięta generalną tezą naturalnego nastawienia, czyli przekonaniem o istnieniu realnego świata, w którym człowiek żyje i działa. I chociaż inaczej niż u Kartezjusza, to fakt niebudzący wątpliwości, pozostaje on faktem zupełnie bezrefleksyjnym ${ }^{30}$, lecz nie dla autorki Życia w petni logos. Podkreśla ona, że świadomość transcendentalna, chociaż intencjonalna, nie dociera do uwarunkowań indywiduum, przez co nie sposób tą drogą pokazać źródeł życia. Nie warunkuje ona samego życia i nie konstytuuje go $^{31}$. Jeśli możliwe jest mówienie o świadomości transcendentalnej, to tylko jak o świadomości ludzkiej żywej istoty, świadomości zapodmiotowanej w ciele człowieka, uźródłowionej w jego mózgu, dzięki któremu ów rozwija sieć wzajemnych powiązań między istotami żywymi, tworząc naukę, filozofię i sztukę - cały świat kultury. Zgodnie z ewolucyjną myślą Tymienieckiej człowiek, czerpiąc siły i energie, jakich dostarcza mu świat przyrody, i tworząc przy ich udziale świat kultury, dostarcza całej sieci życia nowych dynamizmów, poddających ją dalszemu rozwojowi. W tym sensie ludzka świadomość jest transcendentalna. I ten jej sens pogłębia rozumienie zacytowanych wcześniej słów autorki, mówiących o mnożeniu się poziomów rzeczywistości wraz z podejmowaniem przez człowieka działalności interdyscyplinarnej. I ten sens wydaje się uwzględniać Tymieniecka, gdy wskazuje na możliwość rozwoju i wzrastania w siłę samego logos życia za sprawą działalności twórczej kondycji ludzkiej:

29 Zob. ibidem, s. 298.

30 Zob. P. Łaciak, Ciało a redukcja w ujęciu Edmunda Husserla, w: Terytorium i peryferia cielesności. Ciało w dyskursie filozoficznym, red. A. Kiepas, E. Struzik, Studio 29 Michał Motłoch, Katowice 2010, s. 121.

31 Zob. A.T. Tymieniecka, Życie w petni logos, s. 22. 
Kiedy logos życia dojdzie do szczytowego punktu swego konstruktywnego szlaku, dokonuje kompleksowego rozumienia kondycji ludzkiej wewnątrz jedności-ze-wszystkim-co-żyje, jednocześnie samemu podlegając wewnętrznej metamorfozie. Dzięki twórczemu przyborowi swych mocy w kondycji ludzkiej, l o g o s ż y c i a niesie naprzód społeczną nić, prowadzącą ku spełnieniu się wędrówki życia ${ }^{32}$.

Społeczne interakcje mają bowiem doniosły udział w rozwoju zarówno kondycji ludzkiej, jak i powiązanego z nią całokształtu sieci życia.

Za sprawą świadomości człowiek realizuje swe twórcze działanie, a samoświadomość sprawia, że może się temu działaniu „przyglądać", doznając siły logos życia oraz dokonując poznawczego weń wglądu. Samoświadomość jawi nam się, w prezentowanej koncepcji, jako w gruncie rzeczy ostatni przedmiot poznania. Husserla transcendentalna świadomość jest poza światem życia. Samoświadomość w fenomenologii życia jest z tym światem nierozerwalnie powiązana i wewnątrz niego dokonuje swych twórczych i poznawczych aktów. Odkrywanie przez Husserla kolejnych racjonalnych pokładów kultury ludzkiej jest, zdaniem Tymienieckiej, dążeniem do ukazania specyficznie ludzkiego początku, czyli granicy demarkacyjnej między ludzką aktywnością kulturową a przedludzką Naturą. Ale poszukiwanie takiej granicy, twierdzi filozof, to zupełnie chybione przedsięwzięcie ${ }^{33}$.

Na koniec warto podkreślić, że w przekonaniu autorki Życia w petni logos tym, co inspiruje człowieka do intelektualnej pracy badawczej i podejmowania dialogu międzydyscyplinarnego, jest potrzeba poznania sensu życia podsycana świadomością niemożliwości uniknięcia śmierci, świadomością naszej ludzkiej (i nie tylko ludzkiej) skończoności i nieustanym odczuwaniem bólu różnego pochodzenia. Dlatego, drążąc poznawczo niuanse swego życia, człowiek - nie tylko pierwotnie - dochodzi do przekonania, że być, to być żyjącym. Ludzka istota nabiera pewności, że być żyjącym nie można wiecznie. To konsekwencja naszej genezy w świecie istot żywych. Nie zerwiemy związków z nim, ale możemy dążyć do ich zrozumienia i tym sposobem odnalezienia "furtki” ku wieczności ${ }^{34}$. Lecz to, jak się zdaje, stanowi problem wymagający odrębnego potraktowania.

32 Ibidem, s. 21.

33 Ibidem, s. 280-281.

34 Zob. ibidem, s. 304-316. 


\section{Streszczenie}

\section{Anny Teresy Tymienieckiej koncepcja dialogu interdyscyplinarnego}

\section{Słowa kluczowe}

Anna Teresa Tymieniecka; filozofia życia; fenomenologia życia; życie; nauka; żywe jestestwo

Wychodząc naprzeciw odwiecznemu ludzkiemu pragnieniu poznania i zrozumienia Wszystkiego, Anna Teresa Tymieniecka (1923-2014) podjęła dialog interdyscyplinarny z przedstawicielami nauk humanistycznych, społecznych, przyrodniczych oraz ze środowiskiem artystycznym. Polska filozof uznała, że to jedyna droga, którą można dojść do największego celu ludzkości, jaki ostatecznie ukrywa się pod zagadnieniem "poznania i zrozumienia Wszystkiego". To poznanie sensu ludzkiego życia i życia jako takiego zawładnęło umysłem człowieka. Tymieniecka dostrzegła ten kierunek zmagań człowieka zarówno w filozofii, jak i w naukach szczegółowych oraz twórczości artystycznej. Zaproponowała grunt, na którym może, jej zdaniem, dochodzić do interdyscyplinarnego dialogu. Jest nim fenomenologia życia. Fenomenologia życia to metoda, język i krytyka ludzkiego poznania, szeroko określanego jako naukowe.

\section{Summary}

\section{The concept of interdisciplinary dialogue by Anna Teresa Tymieniecka}

\section{Keywords}

Anna Teresa Tymieniecka; philosophy of life; phenomenology of life; the life; science; the living agent

To meet the eternal human desire to know and understand Everything, Anna Teresa Tymieniecka (1923-2014) had taken an interdisciplinary dialogue with representatives of the humanities, social sciences, the natural sciences and with the artistic environment. Polish philosopher found the interdisciplinary dialogue as the only way that you can reach the biggest goal of mankind, which ultimately is hiding under the issue of "knowledge and understanding of Everything". Indeed, this issue is the meaning of human life and of life itself and this question has captured the human mind. Tymieniecka she saw this direction of human struggle both in philosophy and in the natural sciences as well as in artistic creativity. She had proposed a ground for interdisciplinary dialogue. It is the 
phenomenology of life. The phenomenology of life is a method, a language and a critique of human cognition widely defined as the scientific.

\section{Bibliografia}

Szymaniak A., „Anna Teresa Tymieniecka”, w: Encyklopedia filozofii polskiej, red. A. Maryniarczyk, t. 2, Polskie Towarzystwo Tomasza z Akwinu, Lublin 2011.

Tymieniecka A.T., Życie w petni logos, ks. 1: Metafizyka nowego Oświecenia, przeł. M. Wiertlewska, Wydawnictwo Poznańskie, Poznań 2011.

Wiertlewska M., Objaśnienia ważniejszych pojęć, w: A.T. Tymieniecka, Życie w petni logos, ks. 1: Metafizyka nowego Oświecenia, przeł. M. Wiertlewska, Wydawnictwo Poznańskie, Poznań 2011.

Tymieniecka A.T., The Human Condition in-the-Unity-of-Everything-there-is-alive. Individuation, Self, Person, Self-determination, Freedom, Necessity, "Analecta Husserliana. The Yearbook of Phenomenological Research", 2006, vol. 89, book 2 .

Tymieniecka A.T., Poetics as the two faced mirror of the human being In phenomenology and literature, "Analecta Husserliana. The Yearbook of Phenomenological Research" 1982, vol. 12.

Fiut I.S., Zrównoważony rozwój: aspekt filozoficzny i medialny, „Problemy ekorozwoju" 2006, t. 1, nr 2.

Łaciak P., Ciało a redukcja w ujęciu Edmunda Husserla, w: Terytorium i peryferia cielesności. Ciało w dyskursie filozoficznym, red. A. Kiepas, E. Struzik, Studio 29 Michał Motłoch, Katowice 2010. 